\title{
PENGENALAN DAN PELATIHAN E-TAX DALAM RANGKA PENINGKATAN KESADARAN PAJAK PADA UMKM DI KELURAHAN GILINGAN, KECAMATAN BANJARSARI, SURAKARTA
}

\author{
Dra. Siti Hayati Efi Friantin, MM.AK. \\ Dosen D3 Keuangan dan Perbankan
}

efriantin@stie-aub.ac.id

\begin{abstract}
RINGKASAN
Kegiatan pengabdian kepada masyarakat yang dilaksanakan kali ini di Kelurahan Gilingan, Kecamatan Banjarsari, bertujuan memberikan pengetahuan melalui pengenalan dan pelatihan $\mathrm{E}$ - Tax bagi para pengusaha UMKM. Kegiatan pengabdian ini dilaksanakan dalam interval waktu 6 bulan. Dua bulan pertama digunakan untuk survey dan persiapan proposal, dua bulan berikutnya pelaksanaan, dua bulan terakhir untuk pelaporan dan pertanggungjawaban. Peserta kegiatan pengabdian kepada masyarakat ini p-para pengusaha yang memproduksi karak herbal non pengawet yang berpendidikanrendah, Berdasakan situasi ini maka dirasakan dibutuhkan pengenalan dan pelatihan E- Tax dilingkungan UMKM. Pengetahuan E - Tax ini akan mendorong kesadaran pajak dan ketaatan dalam pembayaran pajak kepada negara. Kegiatan pengabdian kepada masyarakat ini sudah dilakukan rutin dan berkesinambungan di wilayah Keluraha Gilingan ini. Kegiatan ini dilakukan dengan metode penyuluhan dan pelatihan E-Tax, selanjutnya akan dilakukan pendampingan untuk mengevaluasi pemahaman peserta

Kata Kunci :Pengenanalan dan Pelatihan E-Tax, Kesadran Pajak
\end{abstract}

\section{PENDAHULUAN}

Peningkatkan kesejahteraan ekonomi rakyat harus dipicu dari rakyat sendiri. Pemberdayakan rakyat akan memuncul usaha mikro, menengah dan kecil, yang sering disebut dengan istilah UMKM. UMKM inilah yang menjadi langkah strategis untuk untuk memperkuat ekonomi kerakyatan, terutama dapat menyediakan lapangan kerja, serta dapat mengurangi kesenjangan dan jurang kemiskinan.. Pada dasarnya pemberdayaan masyarakat perlu dikawal dengan: pemberdayaan bahan baku lokal, technical assistant produksi, serta pengembangan pemasaran. Pertama masyarakat diajari ketrampilan, kemudian dimotivasi untuk menjadi seorang entrepeneurship/ wirausaha, kemudian dibantu bagimana cara memasarkan produknya.

Ketrampilan, keahlian dan daya kreasi seseorang bisa diajarkan melalui bangku sekolah formal, namun juga bisa diajarkan di bangku non formal. Ketrampilan itu bisa muncul dari bakat yang selalu diasah, atau dari bangku sekolahan formal melalui bentuk pelatihan-pelatihan. Namun sayangnya, tidak banyak masyarakat yang beruntung menikmati bangku sekolah, terkadang Sekolah Menengah Atas saja tidak lulus. Tersisih, dan dan hanya bergaul pada kelompok-kelompok masyarakat yang senasib, hidup dengan pendapatan yang pas pasan, dan tidak punya kesempatan mengembangkan usaha.

Kegiatan pengabdian kepada masyarakat yang dilaksanakan di daerah Cinderejo Kidul, Kelurahan Gilingan, Kecamatan Banjarsari, merupakan kegiatan pengabdian yang berkelanjutan. Kegiatan pengabdian ini bukan yang pertama kali dilaksanakan. Masyarakat di daerah Cinderejo Kidul, Kelurahan Gilingan, Kecamatan Banjarsari mereima tim pengabdian dari STIE dengan tangan terbuka dan antusias.

Kegiatan pengabdian kali ini menindaklanjuti dari kegiatan pengabdian sebelumnya. Kondisi di daerah Cinderejo Kidul selama ini sudah terdapat kelompok industri rumahan yang memproduksi karak herbal. Karak herbal adalah karak yang tidak menggunakan bahan pengawet (bleng) .

Produksi karak herbal ini dilakukan per kelompok ibu-ibu PKK yang tergabung dalam kampus pemberdayaan perempuan, yang secara rutin mengadakan perkumpulan maupun rapat-rapat setiap tanggal 5 setiap bulannya.

Produksi karak herbal ini sudah berlangsung lebih dari 5 tahun terakhir ini. Untuk memcukupi kebutuhan bahan dan bumbu produksi karak herbal ini sudah didirikan koperasi produksi secara kecilkecilan.

Koperasi ini masih berskala kecil baik dalam organisasi, dana maupun operasinya. Koperasi ini menyediakan bahan dan bumbu-bumbu yang dibutuhkan pada produksi karak herbal ini.

Namun dalam proses berjalan karena tidak pernah disusun anggaran komprehensif maka sering terjadi masalah dalam mencukupi kebutuhan bahan yang sesuai standar produksi ataupun bumbu yang sama untuk masing-masing kelopok produksi karak herbal ini. 
Berdasarkan analisa situasi diatas maka tim pengabdian kepada masysrakat STIE AUB Surakarta ini tertarik untuk mengangkat judul kegiatan pengabdian kepada masyarakat kali ini adalah " Pengenalan dan Pelatihan E-tax dalam Rangka Peningkatan Kesadaran Pajak pada UMKM di Kelurahan Gilingan, Kecamatan Banjarsari, Surakarta

\section{METODE PELAKSANAAN}

\section{Khalayak Sasaran Strategis}

Sasaran kegiatan pengabdian kepada masyarakat ini adalah pemilik UMKM di di wilayah Surakarta. Pemilik UMKM rata-rata berpendidikan Sekolah Menengah Pertama dan Sekolah Menengah Atas. Selama ini mereka banyak yang belum soal kewajiban pajak apalagi pembayaran pajak lewat internet $(\mathrm{e}-\mathrm{Tax})$. Oleh sebab itu pengenalan dan pelatihan $e-$ Tax ini dirasakan manfaatnya.

\section{Keterkaitan}

Kegiatan pengabdian kepada masyarakat ini merupakan program keberlanjutan dari kegiatan pengabdian sebelumnya yaitu “ Pelatihan Perhitungan Harga Pokok Produksi dan Harga Jual Produk Karak Herbal", kemudian kegiatan pengabdian dengan judul yang berbeda namun ada keterkaitan dengan kegiatan sebelumnya, yaitu "Strategi Menciptakan Kemandirian Ekonomi Rakyat Melalui Optimalisasi Kredit Usaha Mikro, Kecil dan Menengah di Wilayah Surakarta". Namun berdasarkan survey awal, ke lokasi binaan banyak yang mengeluhkan dan menanyakan masalah e - Tax maka kegiatan pengabdian kepada masyarakat kali ini berjudul " Pengenalan dan Pelatihan E-tax dalam Rangka Peningkatan Kesadaran Pajak pada UMKM di Kelurahan Gilingan, Kecamatan Banjarsari, Surakarta

\section{Metode Pelaksanaan}

Metode pelaksaan kegiatan pengabdian kepada masyarakat ini dilakukan melalui arahan,pelatihan ketrampilan dan simulasi. Keterbatasan pendidikan para pesertanya yaitu tingkat pendidikan rendah (SMP dan SMA) inilah yang menjadi alasan. Adapun metode pelaksanaannya dengan cara :

1) Pendekatan "one way" (satu arah) dan Pendekatan Andragogi.

Pendekatan ini secara personal dan kelompok sesuai kebutuhan dan kemampuan peserta. Pendekatan ni dengan meminimalkan pembelajaran dan pelatihan yang menjurus intruksional. Ini diterapkan untuk materi yang pertama : Memberikan pngenalan dan pemahaman tentang pengertian pajak dan pajak penghasilan secara umum.

2) Pendekatan Pelatihan.
Pendekatan ini dengan memberikan pelatihan langsung dari arahan penyaji. Pelatihan ini meliputi pelatihan $e$ - Tax dengan pengenalan proses dan hasil-hasilnya.

\section{Indikator Keberhasilan}

Indikator keberhasilan dari pelatihan ini adalah :

1. Tanggapan dan respon para peserta yang sangat antusias untuk mengenal soal pajak pada umumnya dan $e-$ Tax pada khususnya.

2. Nilai hasil pelatiahan $e-$ Tax ini tidak bisa langsung diuji. Pada dasarnya para peserta mulai memahami bahwa internet bisa membantu pembayaran pajak bahkan tidak perlu ngantri di kantor pajak.

\section{HASIL DAN PEMBAHASAN}

\section{Hasil Program Pengabdian}

Hasil kegiatan pengabdian ini tidak sedikit selain meningkatkan pemahaman para peserta tentang pajak dan $e-\operatorname{Tax}$ namun juga akan meningkatkan kesadaran pentingnya pajak bagi pembangunan negara.

Hasil kegiatan pengabdian ini akan memudahkan para pelaku UMKM melakukan pembayaran kewajiban pajaknya secara on line. Pembayaran tidak perlu mengantri berjam-jam di kantor pajak, mengurangi berkas-berkas dokumen yang harus dibawa, juga mengurangi kesalahan pembayaran. Karena wajib pajak bebas menghitung dan melaporkan sendiri pajaknya.

Tim pengabdian juga diwajibkan menerbitkan laporan kegiatan pengabdian ini dalam format jurnal pada majalah E-Jurnal dan media ilmiah yang lain.

\section{Pembahasan}

Para peserta yang dengan semangat mengikuti pelatihan hingga selesai acaranya.

Sesi pertama, menjelaskan tentang " pengertian pajak dan pajak pnghasilan secara umum " oleh Hanif Safika Rizky, Spd.Mpd kemudian dilanjutkan pelatihan e - Tax oleh Dra. Siti hayati Efi Friantin, MM.AK selaku ketua memberikan penyuluhan,

Pelatihan $e-$ Tax tidak bisa langsung mahir dan trampil. Pendampingan pelatihan diperlukan agar para peserta bisa melakukan sendiri. Pelatihan ini menjadi sangat menarik karena kasus yang diberikan berkaitan dengan kendala dalam pengisian diberikan sebagai contoh kasusnya Evaluasi

1. Evaluasi yang dilakukan dengan cara pelatihan $e-$ Tax secara kelompok, dengan wawancara kasus dan pelatihan.

2. Kriteria evaluasi adalah : ketelitian, kesesuaian kelengkapan dokumen yang menjadi 
prasyarat dengan hasil pengisian $e-\operatorname{Tax}$, memang tidak mudah..

\section{KESIMPULAN DAN SARAN}

\section{Kesimpulan}

Kiat sukses pengisian e - Tax selain bergantung kelengkapan dokumen yang menjadi prasyarat administrasi namun juga tergantung pada ketepatan pengisian e - Tax. Pelatihan ini sangat diperlukan karena akan memudahkan pembayaran dan melaporkan pajak penghasilan usaha UMKM.

Pelatihan ini merupakan kegiatan pengabdian kepada masyarakat yang diharapkan berkelanjutan, dan para peserta sangat menginginkan kemajuan terhadap usaha dan kewajiban pajaknya.. Bahkan mereka menginginkan kunjungan rutin dan berkesinambungan untuk pelatihan-pelatihan pengetahuan dan ketrampilan yang lain.

\section{Saran}

Pelatihan ini terkendala oleh beberapa faktor : kesibukan waktu yang berbeda dari peserta, para peserta yang sifatnya suka rela dan gratis menimbulkan kurangnya kewajiban dan tanggungjawab untuk partisipasi, lemahnya pendidikan, dan jenjang umur yang relative bervariatif dari para peserta mengakibatkan pemahaman untuk menerima tranfer ilmu juga berbeda.

Saran-saran yang bisa diberikan atas kendala yang dihadapi dalam pelaksanaan kegiatan adalah :

1. Waktu pelatihan sebaiknya dihari libur mengingat mereka sibuk kerja dan mengelola usahanya pada hari kerja.

2. Waktu pelatihan tidak harus pagi atau siang, sesuai kesepakatan para peserta. Kalau memungkinkan bisa diberikan pada waktu sore.

3. Pelaksanaan dituntut gratis dan minim biaya, untuk mengatasi kelemahan ini seharusnya diberi kesempatan bekerjasama dengan instansi atau perusahaan lain sebagai pendukung dana pelatihan.

\section{DAFTAR PUSTAKA}

Buku Panduan Billing System

http://prasetyaha.blogspot.com/2012/10/e-

registration.html

http://linaaries.blogspot.com/2010/02/makalah-simpajak-online.html

https://www.ortax.org/ortax/?mod=studi\&page $=$ sho w\&id=35
Peraturan Pemerintah Nomor 74 Tahun 2011 tentang Tata Cara Pelaksanaan Hak dan Pemenuhan Kewajiban Perpajakan

Peraturan Menteri Keuangan Republik Indonesia nomor 32/PMK.05/2014 tentang Sistem Penerimaan Negara Secara Elektronik

Peraturan Direktur Jenderal Pajak Nomor PER 26/PJ/2014 tentang Sistem Pembayaran Pajak Secara Elektronik

Undang-Undang Republik Indonesia Nomor 16 Tahun 2009 tentang Penetapan Peraturan Pemerintah Pengganti Undang-Undang Nomor 5 Tahun 2008 Tentang Perubahan Keempat atas Undang-Undang Nomor 6 Tahun 1983 tentang Ketentuan Umum dan Tata Cara Perpajakan Menjadi Undang-Undang

Undang-Undang Nomor 28 Tahun 2007 tentang Perubahan Ketiga atas Undang-Undang Nomor 6 Tahun 1983 Tentang Ketentuan Umum dan Tata Cara Perpajakan 